\title{
Inclusive Communities: A missional approach to racial inclusivity within the Dutch Reformed Church ${ }^{1}$
}

\author{
Rossouw, Pieter Fourie \\ University of Pretoria \\ fourie@storiesandscience.co.za
}

\begin{abstract}
This article dealt with racial diversity in homogenous white Afrikaans faith communities such as the Dutch Reformed Church (DRC). This study was partially an account of the researcher's own discontent with being a minister in the DRC against the backdrop of his own journey of finding a racially integrated identity in a postapartheid South Africa. It focused on the question of how a church like the DRC can play an intentional role in the formation of racially inclusive communities. The study brought together shifts in missional theology, personal reflections from DRC ministers and contemporary studies on whiteness. The researcher looked towards a missional imaginary as a field map for racial diversity in the church. This was mirrored against contemporary studies on white identity in a post-apartheid South Africa. From this conversation the researcher argued for a creative discovery of hybrid identities within white faith communities. Missional exercises such as listening to the stories of strangers, cross cultural pilgrimages and eating together in strange places can assist congregations on this journey.
\end{abstract}

Keywords

Hybridity, missional imagination, whiteness, diversity

\section{Nightmare on Kerkplein: A narrative of internal discontent}

I woke up with memories from a nightmare. In my dream, I am standing in front of 40000 fellow South Africans. We are gathered at Kerkplein in Pretoria for a local music festival. The crowds are singing and dancing to

1 This research was part of the research done for a MA (Theology) at the Faculty of Theology, University of Pretoria, under the supervision of prof. CJP (Nelus) Niemandt. 
old familiar songs that I remember from camping weekends during the 1980 's when I was part of the 'Landsdiens'. 'Suikerbossie, ek wil jou hê' gets a local African sound with the crowd. A lot more beat than I am used to. I see black, Coloured, Indian, Asian, white, Afrikaans and English, all together. The music moves quickly from one song to another, a medley of childhood choir memories flash past. I am proud and ashamed at the same time. I notice a change in mood. The crowd seems to be changing. I see less and less colour. Only white people remain. In the back of the crowd I see the poet and writer Antjie Krog, begging with her black friends to stay, but they are all leaving. Some other whites are leaving too. I hear Elsabe Zietsman declare: 'Raait, ek is nou klaar.'

It is only then that I notice local Afrikaans singer-songwriter Steve Hofmeyr on the stage. He is wearing a 'toga en 'n wit das'. His pants are the colours of the old South-African flag. The first note from his guitar sends a chill through my spine, yet I get goose bumps all over. My posture becomes military-like. Involuntary, my right hand moves to my heart, holding my chest as if I am about to sing the national anthem. My mouth opens and the words 'Uit die blou van onse hemel' rolls from my tongue, over my lips and falls like dying, bleeding doves on the floor. I feel anger pushing up within me. Somewhere gunshots go off in quick succession and someone in the crowd remarks that another 'boer is murdered'. Steve's voice leads the crowd through the song until the 'kranse antwoord gee...ons vir jou, ons vir jou, ons vir jou Orania.'

I see Antjie crying in the back. I try to pull my hand away from my heart, but I am stuck in this patriotic posture. The crowd gets angrier and more aggressive. The louder the music gets, the less clothes I have on. When the last note is played, I am standing completely naked in front of thousands of people. They look shocked. I look down and notice that my whole body is becoming black from my feet upwards. Only my face is left white. 'Baster! Baster! Baster!' the crowd shouts. Steve hands me his religious robe. I cover my body with this traditional 'toga' worn by the ministers of the Dutch Reformed Church. As I walk off the stage, the garment soaks up the blackness from my skin and I am again white all over. When the music fades and the crowd goes home, the body of a young woman lies dead on the floor. The gunshots we heard earlier came from the barrel of her boyfriend's gun.

No farmer died that day. 


\section{Introduction}

Since the early nineties, Afrikaners have been experiencing a massive identity shift. Alexander (2011:41) reflects on the power of institutions, such as the state, to construct and reconstruct social identities. He then refers to the 'unravelling of the supposedly immutable ('granite') Afrikaner identity that is taking place before our eyes.' Steyn (2001:155) identified this as a postmodern displacement among white South Africans, which includes the Afrikaner community. This displacement is what Anderson (1990:27) calls a 'collapse of a belief system'. Krog (2011:12102) remembers the world of the coloniser as very coherent. She explains that half of her life she functioned entirely in her home language Afrikaans. Reflecting on this post-1994 she argues that South Africans live with splintered identities that are rooted in a long and painful history marked by violent invasions of the other. The Afrikaners in particular found their way of life being fractured by what she calls 'a gradually self-asserting black majority.' (Krog 2009:12112). One could say that a paradigm shift occurred from framing the other as non-white to being framed by the majority others as nonblack. The incoherence, displacement or sense of loss amongst whites is caused by being confronted with the sudden strangeness of white identity on a continent that was framed by a 'master narrative of whiteness.' (Steyn, 2001:3). White being the standard, the norm and everyone else being framed as non-white. It is well recognised in academic literature that when white identity is the standard, whites tend to live unconsciously about the 'profound effect being white has on their everyday lives.' (Steyn, 2001:xxvi; see also Helms, 1998; Gallager, 1999; Hill, 1998). Post-apartheid South Africa have put a magnifying glass on homogenous white identity, forcing whites to acknowledge their white existence as a minor narrative over and against emerging new narratives of black identity.

As a missional theologian, I draw my attention to how these changes in the South African white landscape are playing out in churches that are predominantly white. Through a series of interviews with Dutch Reformed ministers, I reflected on the way the DRC have become a place of safety and familiarity for whites post-1994. Echoing studies on whiteness, I warn that churches like the DRC might find race conversations in South Africa problematic due to the dominant standard of white identity that remains unreflected and in some cases defensive. White churches might find themselves stuck in an identity dead end if this remains the dominant way. 


\section{The DRC: A lager for whiteness?}

As a white church the DRC will have difficulties reflecting critically on its own white identity without the help of other voices. It will find it difficult to participate in emerging identity discourses and opposing cultural paradigms due to the invisibility of white identity and privilege for whites in their homogenous structures. The danger being that the DRC is still unaware of the way its whiteness shape its journey in a post-apartheid South Africa. A difficult road lies ahead for the DRC. The South African society at large is engaging in critical reflections on themes such white privileged. How the DRC will join this discourse remains a challenging task?

Making this task even more challenging is the way people react to a changing environment. Concerning homogenous white faith communities such as the DRC, Niemandt's (2007:37) assessment on faith communities' reaction to change rings true. Churches tend to close up, like a tortoise pulling its head into its shell when danger is near. The danger for white churches like the DRC is the tendency to 'trek laer' in reaction to the growing critical discourse on white identity post-apartheid. Two important questions to reflect upon are to what extend has the DRC become one of a few remaining 'bastions' of the old South Africa and is there a willingness to move beyond the 'lager' within the leadership and congregants?

With these questions in mind, I conducted qualitative interviews with ten ministers from DRC churches in the Western Cape and Gauteng regions (Rossouw 2014). For the purpose of the article, the following common denominators between the ministers can provide helpful context for the reader given the limitations due to the length of the article:

1. None of the participants had any prior information regarding the focus of my research. Only at the end of the interview would I give some feedback on what my research is about.

2. All of them are able to translate their personal experiences in clear reflections and thought through opinions.

3. They are old enough to remember pre-1994 well enough, as well as the transition from the old SA to the new SA and how their respective faith communities played a role in helping them through this transition. 
4. They are all white Afrikaans speaking South-Africans.

5. They are all well informed by the main theological themes of missional theology.

6. All of them have at least 5 years of work experience in the DRC.

7. All of them have worked or are still working in a suburban multiracial context within a mainly white Afrikaans DRC faith community.

The most noteworthy conclusion drawn from the interviews was that all of the ministers expressed a longing for a more culturally diverse community, hoping that their work as ministers in the congregation will help shape their respective faith communities towards becoming more inclusive towards people from other cultures. Yet, these ministers also experienced levels of resistance to change from their congregations, especially when change challenged perceived Afrikaner identity markers, for instance the Afrikaans language.

This resistance, although varied in form and frequency, was interpreted by the respondents as a way to preserve a culture that is perceived to diminishing. As ministers they feel that there exist an expectation within certain sectors of their congregation that the DRC has a role to play towards Afrikaner culture ${ }^{2}$. In all of the conversation it was clear that this expectancy is not representative of the majority members of their respective churches. All of them experience their leadership structure as pro-change and very open towards people of other cultures. The challenge however is that this minority resistance to change has a tendency to make more noise than those who are open to change, resulting in leadership spending a lot more energy and resources on the grievances of a few, thus creating a culture of unnecessary preservation, rather than adaptation.

2 Defining Afrikaner remains a difficult task. Since the end of apartheid, a national cohesiveness is lost, resulting in multi-expressions of cultural identities. A dominant theme in the conversations was the role the Afrikaans language plays in what the ministers perceive to be the cultural 'no-go' area for members. Although different conclusion can be made on why people will have a strong feeling towards worshiping in their home language, it is important to note that most of the ministers interviewed experienced the emphases on Afrikaans as a cultural longing, rather than a spiritual expression. 


\section{Journey towards inclusivity}

Apart from lamenting the pressure to serve the cultural need of a few, the ministers expressed a sense of hope that a journey within the DRC is shaping the imaginations of communities to move beyond being a breeding ground for what they experience as old cultural norms and values. Their discontent with homogeneous whiteness is balanced by a new appreciation for who they are as Afrikaans speaking white South Africans. Their challenge however is to integrate their identities into the larger diverse narratives in South African society.

In creative ways, these ministers have been engaging their congregations about becoming more racially diverse. These engagements were met with positive and negative reactions. Some of the ministers have responded to the negative reactions by turning down the volume of their missional intensity. Others have been encouraged by their colleagues and church councils to pursue this journey regardless of the criticism.

The ways in which racial diversity have been explored differed from congregations to congregation. Ranging from liturgical experiments with other communities, interracial workshops, community development initiatives, outreaches, partnerships between different communities, informal meetings / friendships with ministers and pastors from black faith communities.

Another significant finding was that all of these ministers have a racial sensitivity and cultural awareness that have been deeply influenced by their first experiences as young people going on an outreach to a racially different community. I will explore the role of outreaches later in this article, proposing a shift in language and metaphor that might elevate the ability of such experiences to cultivate diversity.

Niemandt (2007) highlights these experiments as a second reaction to change that is truly a missional reaction and thus the antithesis of the 'laaste bastion' approach. Missional churches move with the change. 'Journey onwards' writes Niemandt (2007:37). Moltmann's (2007) writings on the 'messianic lifestyle' preludes this onward movement. Moltmann argues that a 'closed human being no longer has any hope'. A closed society does not have any future. It 'kills the hope for life of those who stand on its 
periphery'. According to Moltmann, the Christian hope becomes concrete in open community with others. This openness to others is emphasised by other voices outside theology, such as Krog (2014) and Steyn (2001). Racial homogeneous communities, (such as the DRC) needs to intentionally journey towards what Krog (2014:3121) calls 'interconnectedness'. Steyn (2001:168) speaks of 'hybridity' when proposing for more inclusive expressions of fixed cultural identities. She argues that a successful South African society needs communities that are versatile in 'both white and black aspects of society'. An ethos that celebrates syncretism is needed, an ethos that 'applauds the various shades of brown that constitute the human race' Steyn (2001:168). It is at this point of the journey that missional theology becomes an important conversation partner. Having missional theology as a guide along the way is what Russell (2010) defines as an 'interpretive approach that privileges mission as the key to reading the Scriptures'. (see also Roxburgh (2011) interpretation of Heidegger's language house for missiology.)

Van Wyngaard (2014) highlights 'crossing borders' as a central theme in missional theology, stressing the ability of a missional theology to nudge the church towards the other. Newbigin's (1989) work on missional theology's ability to cultivate a spirituality that can welcome cultural plurality without falling into pluralism is well known.

This onward journey, messianic lifestyle, inclusive ethos, interpretation lens or missional language house are shaping formal structures, faith communities and ministers to interpret scripture (and context) in a way that highlights the importance of diversity over and against homogenous cultural identity.

One example is the Highveld Synod (2014) that embraced diversity as key outcome for missional churches. Liani Jansen van Rensburg reported on this in the Afrikaans newspaper Beeld. The article was titled 'NGK gryp diversiteit aan' (the DRC embraces diversity). According to Van Rensburg (2014), this DRC synod had decided to focus on a 'missional calling'.

3 This newspaper report serves as an objective outsider witness to the interpretations of the researcher. The journalist reported on the synod objectively, giving credibility to the DRC's own report on the synod. It also highlights how a broader audience relates to the importance of the theme of diversity for a historically homogenous institution. 
The theme of the synod was 'Veelkleurige gemeentes na 'n veelkleurige gemeenskap' in English translated as 'Colourful congregations towards colourful communities'. In a statement, the newly elected moderator, Hugo van der Linde, told Van Rensburg (2014) 'we chose this theme, because we want to embrace diversity...We want to talk less and do more. We want to do more to cross boundaries and reach people that we would not have reached' (Van Rensburg, 2014). Van Der Linde (2014) also reiterated this thinking with viewpoints published in the Kerkbode, stressing the need for a multi-lingual approach to an otherwise predominant Afrikaans ecclesiology.

It was also reported that the synod experimented with missional exercises. The synod invited people from different backgrounds unfamiliar to the average DRC member attending the synod. 'A conversation exercise was organised that included people from outside the synod. People living on the street, people from Zimbabwe, and even atheists were included in this exercise.' This listening exercise helped the ministers to remove their 'eyepatches', hinting that it helped to break down stereotypes and prejudices. (Van Rensburg, 2014) These exercises during the synod meeting paved the way for attendees to embrace or at least take note of the importance of diversity as a future expression of the Highveld Synod.

These experiments towards inclusivity have the potential to become relevant not just for the DRC's embodiment of a missional imagination, but also relevant to a broader South African context. 20 years into the new democratic South Africa, the country remains a divided society. Instead of being narrowed, the divisions of the past still remain wide and have the potential to grow even wider over time. This is evident in one of the challenges that the country faces, as identified by the National Planning Commission in the National Development Plan: 'Despite progress since 1994, South African society remains divided' (National Planning Commission, 2009). Other voices also echo the NPC. Verwey (2011:120) states that 'the highly unequal nature of South African society' has become an 'acute dimension'. It is common cause that the apartheid legacy is central to understanding the country's divided nature. Alexander writes about 'The South African Nation' (Alexander, 2011:27-43). He explains 'one of the major challenges facing the post-apartheid dispensation is the creative resolution' of the divide-and-rule legacy of apartheid (Alexander, 2011:35). The notion of the 
'rainbow nation' is fading into an expression about the end of the post-1994 euphoria (Alexander, 2011:27). While South Africans struggle, creatively and painfully, to bridge the gaps between a society divided by an unjust past and an increasingly complex present-day reality, missional theology can become an important voice guiding churches to intentionally join the reconciling conversation in a divided South African society.

This, however is easier said than done. Seven months after the Highveld Synod's colourful gathering, the same synod gathered to vote on an alteration to Article 1 of the DRC 'kerkorde' (church order) that would enable communities to embrace the Confession of Belhar ${ }^{4}$ as an optional Confession of Faith. This alteration, although very open in its nature, would have been an important step towards church unity between the DRC and the United Reformed Church in Southern Africa (URCSA). Kritzinger (2014) speaks of the ethos of the Belhar confession as one of 'hope, unity, reconciliation, justice and discipleship'. When this Confession is 'taken up' by a congregation, it will permeate this ethos in every dimension of the congregation's life.

During the floor debate, it was clear that, although certain communities and members responded critically to this alteration not because of the Confession itself, but because of the possible ambiguity of the proposed wording, the dominant pro and against discourse related to the Confession of Belhar and its historical roots. The Highveld Synod, with the colourful ink from the previous synod meeting still fresh on the minutes and press releases, had its first opportunity to take a concrete step towards diversity. The outcome of the vote however was 138 for the proposed amendment and 133 against (Preliminary Minutes, 2015).

It will be difficult to interpret the outcome of the votes solely as a resistance to diversity, but it will be even harder to argue that the outcome is in tune with the synod's missional theme of the previous gathering. The challenge for the DRC will be to bridge the gap between a missional imaginary and

4 The Belhar Confession originated in 1982 from within the Dutch Reformed Mission Church, as part of a Christian response against to Apartheid. In 1986 the document was adopted by the DRMC's synod as a Confession. When the DRMC became the United Reformed Church, the Belhar Confession was included in the standards of unity. (Damon 2013) 
the current embodied ecclesiology of the DRC that have the ability to deconstruct the missional language of diversity. The cliché of walking the talk applies. Block (2009:440) writes that the 'future begins to show up as we gather'. The way we learn from one another can embody our belief in the world we hope to create. The way we gather can also deconstruct the content of the gathering. There needs to be a more intentional link between learning, talking and praying the language of a missional imagination and embodying it creatively in the practices of our gatherings. To bridge this, I propose three embodied practices or experiments that are exercised over time in community with others. They are, liturgical listening, linguistic pilgrimages and sacred meals in humble places.

\section{Missional practices for inclusivity}

\section{Liturgical listening}

Discernment is a central praxis of a missional church. A common thread of dialogue and listening runs through the development of missional theology. Liturgical listening refers to a congregation's ongoing discernment journey that involves all dimensions of the congregation's life. It is where the missio Deo and coram Deo meet. In the congregation where I work we have asked the question 'Where do you live, work, play and pray?' as a discernment question, inviting the congregation to reflect ordinariness of life as a missional act before a missional God. I argue that discernment takes time and the metaphor of liturgy can invite the church to adopt a more open, patient, rhythmic approach to discernment. For Roxburgh (2011:176) this will be a deeper way of listening: 'listening each other into speech.' It is a way of listening that frees people to share their stories in a deep and truthful way. Missional listening involves the skill of creating these safe spaces. The example of the Highveld Synod's listening exercises are helpful in this regard. However, it is important to note that when a homogenous white body like the Highveld Synod attempts this type of engagement exercises across cultures, a posture of humility is crucial. It should guard against what can be called the 'rudeness of whiteness'. Reflecting on the linguistic roots of indigenous South African terms for white people in languages such as Sesotho, Krog (2007) highlights the connection between arrogance/rudeness and whiteness. When a white person acts against the 
grain of this historical experience of whiteness, the old Basothos used to say: 'Ga se lekgoa, ke motho' - She/he is not white, she/he is a human.' (Krog 2007:11003)

Roxburgh's (2011:51) trinitarian framework for the conversation about a missional life within a changing context will also be helpful: 'Trialogue (a three-way conversation) between gospel, church, and culture.' The church is in conversation with the neighbourhood, engaging the local police, schools, medical institutions, community forums and other faith communities. The church engages with culture's feedback about its own identities. The church reflects critically about itself with humility and openness. Adopting this framework at congregational level, the church will be able to experiment in fun yet challenging listening spaces in partnership with poets, writers, artists, journalists, activists within a diverse community. In the culturally diverse South African context, these acts of listening will become increasingly important platforms through which the DRC not only rediscover its own identity afresh, but discerns the voice of God for its place, role and context within the broader Christian community.

\section{Linguistic pilgrimages}

Linguistic pilgrimages refer to the ability of a journey such as an outreach or a mission trip to either reveal the language of the community or change it in a profound way. This concept also invites the congregation to intentionally gather in different locations as a way of listening to the community, but more so be changed by the new and strange environment.

Outreaches play a big part in DRC communities. It has been a guide towards inclusivity for many. The language of outreaches however can reveal a memory of colonialism. In the DRC congregants often reach out to those less fortunate, those who cannot help themselves, those who lack the skills to make it on their own. Historically the beneficiaries of these initiatives are mostly black people. The movement of power and privilege remained constant: White reaching out to Black - white remaining on top, black negated to the bottom. White is right, black needs change. Whites are called, blacks are calling. Without realising, this way of looking at church outreach projects instils the feeling of superiority, as if white people are the benevolent custodians of black people. 
It is important that we refrain from such a needs-deficiency approach to communities. Such an approach paints the DRC as the solution and the community as the problem. If this posture remains, The DRC will find increasing resistance from younger black voices regarding outreaches. Community development initiatives started with the best intentions in mind will fail, if all it does, is instil the notion of black inferiority versus white superiority. Rather, the DRC must approach these previously disadvantage communities as spaces filled with fellow human beings busy adapting to their circumstances in a multitude of creative ways. In this sense the metaphor of pilgrimage might be of special importance.

Pilgrimage invites DRC communities to explore and appreciate not only their known neighbourhoods, but also those on the other side of the highway. The challenge will be to tread lightly on the sacred ground of others. Tom Smith (2014) uses this metaphor of a pilgrimage as a way to talk about activities such as an outreach. Smith (2014:2132-2137) shares a story of how he took his church's finance team on a pilgrimage to a nearby informal settlement.

He concludes the story by saying their 'pilgrimage' ended in a little shebeen where the group ordered a round of beers. Instead of each person receiving a beer, one big bottle was placed in front of them. At this shebeen, the custom was to share the $750 \mathrm{ml}$ bottles between groups of friends. The beer turned out to be a gift by the owner of the shebeen. Smith (2014:2137) reflects on this alternative budget meeting as an activity that changed the language of their own community. Linguistic pilgrimages involve both intentional linguistic experiments and the openness to learn new vocabularies while moving the body into a different posture of being.

In this posture, the DRC is not called or sent into the world of the community, but rather invited by God through the community. The community becomes the agent of change, the sacred guide to a deeper understanding of self and a new appreciation of the other. ${ }^{5}$

5 Critique on this practice is necessary. Initiatives like this can easily fall into the trap of 'white tourism'. The idea of whites going into black townships for an experience should be heavily deconstructed. This can be countered by being invited, which implies a mutual relationship established over a period of time. DRC congregations who wish to practise this, should be very aware of how easily the old power narratives comes into play. 


\section{Sacred meals with strangers}

In the midst of her reflections on her own cultural identity, Krog (2011:1804) remembers with 'blue clarity' her family's rusks recipe. 'Boerbeskuit' is an Afrikaner delicatessen, made from sourdough cultures passed on from generation to generation. It is noteworthy how Krog can seamlessly move between writing about the complexities of her friendship across the racial lines drawn by apartheid's legacy and reflections on her mother's 'boerbeskuit' recipe. Peterson (2006:71) claims that 'our common humanity is out in the open' when we eat together. This common humanity echoes the interconnectedness or hybridity as mentioned earlier in this article. Sharing a meal with a stranger, against the backdrop of a missional imaginary that journey onwards towards inclusivity becomes a sacred act. It has the potential to weave us into this interconnectedness. In a context of homogeneity, from a missional perspective, the focus moves from 'We are what we eat' to 'We are with whom we eat'. Food, in a way, becomes a language house. The table becomes the dictionary for our preconceived ideas about the world. Food talks. It reveals the stories of our being. On the one hand our eating habits and rhythms reflect our privilege or lack thereof, our whiteness and blackness, our ability to exclude or include, our cultural preferences and the unjust gaps between rich and poor. It also highlights and often celebrates our different heritages, our shared love for life, our passions, our unique humours, our friends, our need for belonging, our common humanity. Roxburgh (2011:142) writes that for 'humans to flourish, we need to be embedded' in a sacramental way of living. A missional-sacramental way of eating involves eating with strangers in locations that are strange to us. We are what we eat, with whom we eat and where we eat. (see also Keifert's (1992) work on liturgy and hospitality)

DRC congregations who wish to embody a more inclusive way of being can, for example be creative in re-interpreting the kerkbazaar (church fete). An example of this includes: Partnering with a church, school of organisation from a different cultural background; finding a different location that is unfamiliar to the everyday rhythms of the congregation and choosing diversity themes that encourages them to incorporate foods of different cultures. 


\section{Conclusion}

The opening story in this article is a dreamlike narrative reflecting on an actual cultural occurrence not so long ago. It was intentionally left open ended with the aim to form a metaphoric background for the theological reflections that followed. It also sets my own interpretive lens on the foreground. Since the end of apartheid, the validity for homogenous white expressions have been challenged, yet the all-white embodiments of our history survived especially in institutions like the DRC. The reasons for this varies, but the sustainability of it becomes more and more questionable. Against a missional imagination of cultural diversity it becomes even more problematic to sustain an all-white ecclesia. Ministers in these congregations feel it in their theological gut that their churches need to change. The DRC needs to become more culturally inclusive in the coming years. In the meantime, culturally homogenous faith communities in South Africa can either add to the preserving of stereotypes or at least play an important role in breaking down the barriers that exist between all the others that make up the South African social landscape. It starts with how we talk about God, ourselves and each other. I am hopeful about how missional theology has been colouring the language house of the church I belong to, making it more inviting for others to find their place and more encouraging for others to leave their place, on this journey towards interconnectedness. This interconnectedness or inclusivity can be embodied in creative (and may I say fun?) missional practices, such as outreaches with a pilgrimage posture, safe spaces for deep and ongoing listening to each other and habitual sharing of meals with strangers in locations that challenge preconceived ideas about each other.

\section{Bibliography}

Alexander, N 2001. Opinion Pieces by South African Thought Leaders. Johannesburg: Penguin Books.

Block, P 2009. Community: The Structure of Belonging. Berrett-Koehler Publishers. Kindle Edition. 
Damon, S 2013. From the Heart of God: A Study of the Belhar Confession. [Online]. Available: https//www.crcna.org/sites/default/files/FromtheHeart_ studyguide.pdf

Gallagher, CA 1997. White racial formation: Into the twenty-first century. In R Delgado and J. Stefancic (eds.), Critical white studies: Looking behind the mirror, pp 6-11. Philadelphia: Temple University Press.

Helms, J 1998. Towards a Model of White Racial Identity Development. In College Student Development and Academic life. Routledge Publishers. London

Hill, M 1997. Whiteness: A critical reader. New York University Press.

Keifert, PR 1992. Welcoming the Stranger: A public theology of worship and evangelism. Fortress Press, Minneapolis.

Kritzinger, JNJ 2014, 'Concrete spirituality' HTS Teologiese Studies/ Theological Studies 70(3), Art. \#2782, 12 pages. http://dx.doi.org/10.4102/hts. v70i3.2782

Krog, A 2009. Begging to be black. Random House Struik (PTY) Ltd, Cape Town [Kindle edition].

Moltmann, NJ 2007. The Open Church: Invitation to a Messianic Lifestyle. Fortress Press.

Newbigin, L 1989. The Gospel in a Pluralist Society. Wm. B. Eerdmans Publishing Co. Grand Rapids, Michigan.

Niemandt, N 2007. Nuwe Drome vir Nuwe Werklikhede.

Geloofsgemeenskappe in pas met ' $n$ postmoderne Wereld. Lux Verbi.BM.

Pillay, RS and Durrheim, K. A Disgraced Whiteness: Tactics Used to Deny Racism, Reduce Stigma, and Elicit Sympathy. [Online]. Available: http://www.mmg.mpg.de/fileadmin/user_upload/Subsites/Diversities/ Journals_2014/2014_15-02_5_Pillay_Durrheim.pdf

Preliminary Minutes, 2015. Highveld Synod

Rossouw, PF 2014. Hibridity: A Missional Approach to Inclusivity. Unpublished master's thesis. Pretoria: University of Pretoria. 
Roxburgh, AJ 2011. Missional. Joining God in the neighbourhood. Baker, Grand Rapids. [Kindle edition].

Roxburgh, AJ and Boren, MS 2009. Introducing the Missional Church.

What it is, Why it matters, how to become one. Grand Rapids: Baker.

Russell, DB 2010. What Is a Missional Hermeneutic? [Online]. Available:

http://www.catalystresources.org/what-is-a-missional-hermeneutic/\#sthash.tFx07ZA0. dpuf

Smith, Tom 2014. Raw Spirituality: The Rhythms of the Jesus Life. Renovare Resources InterVarsity Press. Kindle Edition

Steyn, ME 2001. Whiteness Just Isn't What It Used To Be. White Identity In A Changing South Africa. State University of New York Press Albany

Van Rensburg, L 2014. NGK gryp diversiteit aan. Beeld, 12 September:12

Van Wyngaard C 2014. 'White Christians Crossing Borders: Between perpetuation and transformation'. In Michael, L \& Schulz, S (eds.) Unsettling Whiteness. Inter-disciplinary Press, pp. 191-202.

Verwey 2001. Opinion Pieces by South African Thought Leaders. Johannesburg: Penguin Books. 